Kastamonu Eğitim Dergisi
$\begin{aligned} & \text { Kastamonu Education Journal } \\ & \text { Ocak 2020 Cilt:28 Sayı:1 } \\ & \text { kefdergi.kastamonu.edu.tr }\end{aligned}$

\title{
Güzel Sanatlar Liselerindeki Türk Sanat Müziği Teori Ve Uygulaması Dersine Yönelik Öğretmen Görüşleri
}

\section{Teacher Opinions On Turkish Art Music Theory And Practice Course In Fine Arts High School}

\author{
Öz \\ Hande Nur AŞIK GÖKÇE ${ }^{1}$, Gökhan ÖZDEMIR²
}

Araştırmanın amacı, Güzel Sanatlar Lisesi Öğretim Programı'nda yer alan “Türk Sanat Müziği Teori ve Uygulaması” dersinin içeriği ve işlenme şekli ile ilgili öğretmen görüşlerine dayalı olarak değerlendirme yapmaktır. Araştırma, durum tespitine dayalı betimsel bir çalışmadır. Araştırmanın çalışma grubunu, Türkiye'nin farklı bölgelerindeki Güzel Sanatlar Liselerinden rastgele seçilen 16 Müziksel İşitme Okuma ve Yazma branş öğretmeni oluşturmaktadır. Araştırmanın durum saptama ve değerlendirme niteliğinde olması nedeniyle veri toplama aracı olarak yarı yapılandırılmış ve yapılandırılmış olmak üzere iki bölümden oluşan görüşme formu hazırlanmıştır. Verilerin çözümlenmesinde, frekans, yüzde, aritmetik ortalama kullanılmıştır. Yarı yapılandırılmış sorulardan oluşan görüşme formlarındaki veriler ise betimsel analiz tekniği ile özetlenip yorumlanarak analiz edilmiştir. Bu araştırma sonucunda; ders kitabının içeriğinin yeterli bulunmaması sebebiyle kullanılmadığı, makamların tampere sisteme uyarlanarak aktarıldığı, dersin kazanımlarının belirlenen sürede yetiştirilemediği ve bu dersin sınıf düzeyine uygun olmadığı tespit edilmiştir. Elde edilen sonuçlar çerçevesinde kazanımların ve dersin uygulanabilirliğinin arttırılmasına yönelik önerilerde bulunulmuştur.

Anahtar Kelimeler: güzel sanatlar lisesi, müzik eğitimi, öğretim programı, türk sanat müziği teori ve uygulaması dersi, öğretmen görüşleri.

\section{Abstract}

The aim of the research is to evaluate the contents and the way of processing of the "Turkish Art Music Theory and Practice" course in the Fine Arts High School Teaching Program based on the teachers 'opinions. Research is a descriptive study based on situational awareness. The working group of the study randomly selected from different regions of the Fine Arts High School Musical Hearing, Reading and Writing 16 branch teachers. Due to the fact that the study is a status assessment and evaluation, a two-part interview form has been prepared as a data collection tool, semi-structured and structured. In the analysis of the data, frequency, percentage, arithmetic mean are used. Data on the interview form consisting of semi-structured questions were analyzed with the descriptive analysis technique summarized and interpreted. As a result of this research; it was determined that the contents of the textbook were not used due to insufficient content, the authorities were adapted to the tamper system and the achievements of the course could not be raised within the specified time and this course was not suitable for the class level. Suggestions have been made to increase the achievements and the applicability of the course within the scope of the results obtained.

Keywords: fine arts high school, music education, education curriculum, turkish art music theory and practice course, teacher opinions 


\section{Extended Abstract}

Purpose: Considering that the units, subjects and acquisitions of the lesson "Turkish Art(Classical) Music Theory and Application" must be taught in 9th and 10th class levels, this lesson is considered to be complicated. Because of this prognosis, which is the starting point of the study, opinions of teachers, who teach this course in Fine Arts High Schools in various regions of Turkey, are gaining importance. When viewed from this aspect, the purpose of the study is to evaluate the current situation (about the way teachers teach this course and content of the course) comprehensively based on the opinions of teachers. After the situation being evaluated, by offering suggestions for more efficient teaching, it may stimulate and lead researchers for new studies about the subject.

Method: In this study, the mixed method, which includes qualitative and quantitative methods, has been used. It is a descriptive model study based on determination of the state. In this study, making a national and international literature review specifies some states contributing to development of data collection tools. For the rough questionnaire, the researcher has taken expert opinions. After applying some required changes on the questionnaire, the necessary data were collected from the working group. Since the study is based on the determination and evaluation of a state, semi-structured and fully structured interview form, consisting of two sections, was prepared. In order to detect the internal consistency of the first section of the form, Cronbach Alpha was calculated. In the analysis of the collected data, frequency, percentage and arithmetic average were used. The data collected from the second section of the form, which is semi-structured, was summarized by the method of descriptive analysis. The working group of this study includes 16 randomly selected teachers of this course from various regions and high schools in Turkey.

Findings: According to the analyzed data, 56,3\% of teachers use the book "Turkish Art(Classical) Music Theory and Application" which has been published by the Ministry of National Education. Only few teachers $(6,3 \%)$ find the book fruitful. When viewed from this aspect, it is possible to tell that the teachers uncommonly use this book since most of them do not find it efficient. The research has revealed that $56,25 \%$ of the teachers do not use a source book at all. The book, which was published by the Ministry of National Education of Turkey, is mostly not considered to be a useful source and is not used often. Contrarily to the current state, the range of not using the book appears to be quite wide. It is also possible to say that $68,8 \%$ of the teachers use Turkish scale system by adjusting well-tempered, western scale system. This may indicate that the teachers are unable to teach students the original pitches of sounds in Turkish music system (known as "koma") in the way it is presented in the book prepared by the ministry. $56,3 \%$ of teachers teaches "koma" sounds in traditional and usual way. Accordingly, it is possible to say that teachers do not often transpose music notes during teaching. It is possible to say that without transposing the notes for solfeggio, it may be hard for students to sing properly as they may have inadequate registers for vocal singing. $62,5 \%$ of the teachers indicate that learning outcomes of this course are unable to be efficiently completed in a period that was determined in the curriculum. That is to say, teachers are unable to reach their goals in the pre-determined period of teaching. $81,25 \%$ of the teachers indicate that they often use the piano in Turkish Art(Classical) Music Theory and Application course. Accordingly, it is possible to tell that, it is not suitable to gain all the acquisitions from this course since teachers use only the piano as a teaching material/instrument. Besides, it is important to say that the teachers find this course being not proper for 9 th and 10th class levels.

Results: As a conclusion, it is obvious that most of the teachers do not find the book "Turkish Art (Classical) Music Theory and Application" useful and do not use it often. It was detected that the teachers mostly make transposition into well-tempered scale system in order to teach different Turkish music scales. It has been also detected that the teachers are unable to complete the foreseen acquisitions of this course in time. According to the data, it is clearly seen that the piano is the only instrument used in Turkish Art (Classical) Music Theory and Application lesson. Moreover, teachers emphasize that this course is too hard for the students who take this course in 9th and 10th class levels. 


\section{Giriş}

Müzik; toplumların, kültürlerin, insanların, zamanların ve coğrafyaların farklılıklarına göre değişen aynı zamanda gelişen bir olgudur ve bu bağlamda incelenmesi - değerlendirilmesi gerekmektedir. Bütün bu farklılıklar aynı zamanda farklı müzik türlerinin doğmasına da sebep olmuştur. Oluşan yeni müzik türleri, kültürel etkileşimler sonucunda birbirleriyle sentezlenerek yeni icra türlerine, bu yeni icra türleri de çalgıların ve çalgı icralarının geliştirilmesine olanak sağlamıştır.

Farklı müzik türleri ile karşılaştırıldığında Türk müziğinin gelişme çizgisi, diğer toplumların sahip olduğundan daha çeşitli ve zengindir. Kendi içyapısındaki çeşitlilik onu ayrı bir inceleme konusu yapmakta ve özellikle makamsal kökeni onun en derin özelliğini oluşturmaktadır. Türk müzik kültürünü incelemek, sadece seslerin, ses aralıklarının ve perdelerin nasıl elde edildiğini anlamak değil, aynı zamanda bu alandaki tecrübelerin ortaya çıkardığı fikirleri, musikinin yorumlanmasıyla uyanan duygular arasındaki ilişkileri, musikide kullanılan çeşitli temalar ile üslupların kavramsallaşmasını da incelemek demektir (Popescu - Judetz, 2007, 13).

Hindemith Türk müziği eğitiminin önemini şu sözler ile dile getirmiştir; "Bir halk şarkısının gerçek değeri, geride bıraktığı müzikal etkide değil, şarkıcıda folklorik, coğrafi ve tarihsel ilişkileri uyandıran duygularda saklıdır. Bunlar ise, Türk öğrencilere yabancı halk şarkıları ile verilmez. Bundan dolayı, okul müzik derslerinin şarkı dağarı, eski güçlü Türk halk müziğinin muhteşem zengin dağarından çıkarılmalıdır"(Gedikli, 1999, 80). Türk müzik kültürünün önemli bir dalı olan Türk Sanat Müziği, bugünün kuşaklarına modern metotlarla ve güçlü eğitimsel yöntemler ile öğretilir ise bu sanat dalı gelecek nesillere sağlam temeller üzerine oturtulmuş olarak emanet edilebilecek ve dünyanın diğer tanınmış kültürleri arasında hak ettiği yeri alması sağlanabilecektir (Kuyucu, 2010, 12).

2016 yılında değişen Güzel Sanatlar Liseleri Öğretim Programı ile Müzik Bölümü zorunlu alan dersi olan Müziksel Işitme Okuma ve Yazma Dersi üç farklı türe bölünmüştür. Bunlar Batı Müziği Teori ve Uygulaması, Türk Sanat Müziği Teori ve Uygulaması, Türk Halk Müziği Teori ve Uygulaması Dersleri şeklindedir. 2016 yılı itibariyle kademeli olarak geçiş yapılan yeni öğretim programında, Batı Müziği Alanı seçen Güzel Sanatlar Liseleri 9 ve 10. Sınıf düzeylerinde Müziksel İşitme Okuma ve Yazma Dersi yerine Batı Müziği Teori ve Uygulaması ile Türk Sanat Müziği Teori ve Uygulaması derslerini işlemeye başlamışlardır. Batı Müziği Teori ve Uygulaması Dersi içeriğindeki kazanımlar Müziksel Işitme Okuma ve Yazma Dersi ile benzer düzeydedir. Yeni eklenen Türk Sanat Müziği Teorisi ve Uygulaması Dersi ise farklı kazanımlara sahiptir. Ortaöğretim Genel Müdürlüğünün yayınladığı Türk Sanat Müziği Teori ve Uygulaması Dersi Öğretim Programında bu dersin amacı; geçmişten beri varlığını koruyan geleneksel sanat müziği repertuarını günümüz modern eğitim anlayışı ile işleyerek geçmiş ile bugün arasında bağ oluşturmak ve sanat müziğinin icrasının temel prensiplerini öğrenciye kazandırmak şeklinde belirtilmiştir.

Türk Sanat Müziği Teori ve Uygulaması Dersi Öğretim Programı, 1739 sayılı Millî Eğitim Temel Kanunu'nun 2. maddesinde ifade edilen Türk Millî Eğitiminin Genel Amaçları ile Türk Millî Eğitiminin Temel illkeleri esas alınarak hazırlanmıştır (TTKB, 2016, 4).

Bu programla öğrencinin;

1. Türk sanat müziğinde günümüzde kabul edilen Arel-Ezgi ses sistemi kapsamında geleneksel perdelerimizi, aralık bilgisini, usul bilgisini ve makam kavramını anlaması,

2. Çeşitli makamlarda oluşturulmuş seyirleri usul vurarak okuması,

3. Makamların anlatımında, sözlü eserlerin solfejini ve sözlerini okuması,

4. Öğrendiği eserleri çalgısında uygulaması,

5. Eserleri çeşitli kararlardan (perdelerden) çalması,

6. Milî ve manevi değerlerimizi konu edinen eserleri ekleyerek repertuvarını genişletmesi,

7. Ülkemizin musiki kültürüne hizmet etmesi hedeflenmiştir.

Türk Sanat Müziği Teori ve Uygulaması Dersi Öğretim Programı'yla öğrencilere kazandırılması hedeflenen beceriler;

1. Göçürme (tranpozisyon) yapma

2. Usul vurma

3. Makamları çalgısında uygulama

4. Temel müzik terimlerini doğru ve yerinde kullanma

5. Müziksel yazma

6. Müziksel okuma (solfej)

7. Müziksel algılama

8. Müziksel işitme (dikte yapma) 
9. Tonalite ve modalite (makam tanıma)

10. İcra (yorumlama)

11. Analitik düşünme

12. Türkçeyi doğru, güzel ve etkili kullanma

13. Bilgi ve iletişim teknolojilerini kullanma

14. İş birliği

15. Zaman yönetimidir. ise şöyledir:

Türk Sanat Müziği Teori ve Uygulaması Dersi Öğretim Programının sınıflar bazında ünite, konu ve kazanımları

9. Sınıf Türk Sanat Müziği Teori Ve Uygulaması Dersi Öğretim Programı Ünite, Konu Ve Kazanımları

9.1. PERDE, ARALIK, DÖRTLÜ VE BEŞLILER

9.1.1. Perde ve Aralık Kavramı, Koma Değerleri, Harf Sembolleri

9.1.1.1. Çargâh makamı dizisindeki perdeleri tanır.

9.1.1.2. Hüseynîaşiran-acemaşiran perdelerinin aralık değerinin 4 koma olduğunu kavrar.

9.1.1.3. Buselik-çargâh perdelerinin aralık değerinin 4 koma olduğunu kavrar.

9.1.1.4. Diğer perdelerin aralık değerini gösterir.

9.1.1.5. 4 komalık aralığın $B, 9$ komalık aralığın T harfiyle gösterildiğini kavrar.

9.1.2. Koma Cetveli ve Tablosu

9.1.2.1. Koma cetvelindeki Türk sanat müziği değiştirici işaretleri, harf karşılıkları ve koma değerlerini açıklar.

9.1.2.2. Koma cetveli ve tablosu ile ilgili hazırlanmış alıştırmaları çözer.

9.2. USULLER

9.2.1. 2 Zamanlıdan 7 Zamanlıya Kadar Usuller

9.2.1.1. Nim sofyan usulünde yazılmış ezgileri usul vurarak okur.

9.2.1.2. Semai usulünde yazılmış ezgileri usul vurarak okur.

9.2.1.3. Sofyan usulünde yazılmış ezgileri usul vurarak okur.

9.2.1.4. Türk aksağı usulünde yazılmış ezgileri usul vurarak okur.

9.2.1.5. Yürük semai usulünde yazılmış ezgileri usul vurarak okur.

9.2.2. 8 Zamanlıdan 10 Zamanlıya Kadar Usuller

9.2.2.1. Devrihindi usulünde yazılmış ezgileri usul vurarak okur.

9.2.2.2. Devrituran usulünde yazılmış ezgileri usul vurarak okur.

9.2.2.3. Düyek usulünde yazılmış ezgileri usul vurarak okur.

9.2.2.4. Müsemmen usulünde yazılmış ezgileri usul vurarak okur.

9.2.2.5. Aksak usulünde yazılmış ezgileri usul vurarak okur.

9.2.2.6. Oynak usulünde yazılmış ezgileri usul vurarak okur.

9.2.2.7. Raks aksağı usulünde yazılmış ezgileri usul vurarak okur.

9.2.2.8. Aksak usulünde yazılmış ezgileri usul vurarak okur.

9.2.2.9. Curcuna usulünde yazılmış ezgileri usul vurarak okur

9.3. MAKAMLARIN OLUŞUMU

9.3.1. Basit Makamları Oluşturan Dörtlü-Beşliler ve Göçürme Çalışmaları

9.3.1.1. Basit makamların oluşmasındaki temel mantığı açıklar.

9.3.1.2. Basit makamları oluşturan dörtlü ve beşlileri eksiksiz sayar.

9.3.1.3. Basit dörtlü-beşlilerin kalıplarını başka perdeler üzerine göçürme alıştırmalarını çözer.

9.3.1.4. Basit dörtlü ve beşlileri seslendirir.

9.3.2. Özel Dörtlü ve Beşlilerde Kalıplar ve Göçürmeler

9.3.2.1. Özel dörtlü ve beşlilerin adlarını açıklar.

9.3.2.2. Özel dörtlü ve beşlilerin kalıplarını açıklar.

9.3.2.3. Özel dörtlü ve beşlileri başka perdelere göçürür.

9.3.2.4. Özel dörtlü ve beşlileri seslendirir.

9.3.3. Türk Müziğinde Makam Kavramı ve Makam Türleri

9.3.3.1. Makam teriminin kökenini açıklar.

9.3.3.2. Müzik terimi olarak makamın anlamını açıklar.

9.3.3.3. Türk müziğindeki makam türlerini ifade eder. 


\subsection{MAKAMLAR}

9.4.1. Çargâh, Mahur ve Acemaşiran Makamı

9.4.1.1. Çargâh, mahur ve acemaşiran makamlarının hangi dörtlü ve beşlilerden oluştuğunu açıklar.

9.4.1.2. Çargâh, mahur ve acemaşiran makamlarının perdelerini sırasıyla sayar.

9.4.1.3. Karar, yeden ve güçlü perdelerini söyler.

9.4.1.4. Çargâh, mahur ve acemaşiran makamlarında yazılmış seyirleri usul vurarak okur.

9.4.1.5. Çargâh, mahur ve acemaşiran makamlarındaki eserleri usul vurarak okur.

9.4.2. Buselik Makamı

9.4.2.1. Buselik makamının hangi dörtlü ve beşlilerden oluştuğunu açıklar.

9.4.2.2. Buselik makamının perdelerini sırasıyla sayar.

9.4.2.3. Karar, yeden ve güçlü perdelerini söyler.

9.4.2.4. Buselik makamında yazılmış seyirleri usul vurarak okur.

9.4.2.5. Buselik makamındaki eserleri usul vurarak okur.

9.4.3. Kürdi Makamı

9.4.3.1. Kürdi makamının hangi dörtlü ve beşlilerden oluştuğunu açıklar.

9.4.3.2. Kürdi makamının perdelerini sırasıyla sayar.

9.4.3.3. Karar, yeden ve güçlü perdelerini söyler.

9.4.3.4. Kürdi makamında yazılmış seyirleri usul vurarak okur.

9.4.3.5. Kürdi makamındaki örnek eserleri usul vurarak okur.

9.4.4. Rast Makamı

9.4.4.1. Rast makamının hangi dörtlü ve beşlilerden oluştuğunu açıklar.

9.4.4.2. Rast makamının perdelerini sırasıyla sayar.

9.4.4.3. Karar, yeden ve güçlü perdelerini söyler.

9.4.4.4. Rast makamında yazılmış seyirleri usul vurarak okur.

9.4.4.5. Rast makamındaki eserleri usul vurarak okur.

9.4.5. Uşşak Makamı

9.4.5.1. Uşşak makamının hangi dörtlü ve beşlilerden oluştuğunu açıklar.

9.4.5.2. Uşşak makamının perdelerini sırasıyla sayar.

9.4.5.3. Karar, yeden ve güçlü perdelerini söyler.

9.4.5.4. Uşşak makamında yazılmış seyirleri usul vurarak okur.

9.4.5.5. Uşşak makamındaki eserleri usul vurarak okur.

9.4.6. Hüseyni ve Muhayyer Makamları

9.4.6.1. Hüseyni ve muhayyer makamlarının hangi dörtlü ve beşlilerden oluştuğunu açıklar.

9.4.6.2. Hüseyni ve muhayyer makamlarının perdelerini sırasıyla sayar.

9.4.6.3. Karar, yeden ve güçlü perdelerini söyler.

9.4.6.4. Hüseyni ve muhayyer makamlarında yazılmış seyirleri usul vurarak okur.

9.4.6.5. Hüseyni ve muhayyer makamlarındaki eserleri usul vurarak okur.

$>$ 10. Sınıf Türk Sanat Müziği Teori Ve Uygulaması Dersi Öğretim Programı Ünite, Konu Ve Kazanımları 10.1 MAKAMLAR

10.1.1. Segâh Makamı

10.1.1.1. Segâh makamının hangi dörtlü ve beşlilerden oluştuğunu açıklar.

10.1.1.2. Segâh makamının perdelerini sırasıyla sayar.

10.1.1.3. Karar, yeden ve güçlü perdelerini söyler.

10.1.1.4. Segâh makamında yazılmış seyirleri usul vurarak okur.

10.1.1.5. Segâh makamındaki eserleri usul vurarak okur.

10.1.2. Hicaz ve Hicaz Hümayun Makamı

10.1.2.1. Hicaz ve hicaz hümayun makamlarının hangi dörtlü ve beşlilerden oluştuğunu açıklar.

10.1.2.2. Hicaz ve hicaz hümayun makamlarının perdelerini sırasıyla sayar.

10.1.2.3. Karar, yeden ve güçlü perdelerini söyler.

10.1.2.4. Hicaz ve hicaz hümayun makamlarında yazılmış seyirleri usul vurarak okur.

10.1.2.5. Hicaz ve hicaz hümayun makamlarındaki eserleri usul vurarak okur.

10.1.3. Hicaz Uzzal ve Zirgüleli Hicaz Makamları

10.1.3.1. Hicaz uzzal ve zirgüleli hicaz makamlarının hangi dörtlü ve beşlilerden oluştuğunu açıklar. 
10.1.3.2. Hicaz uzzal ve zirgüleli hicaz makamlarının perdelerini sırasıyla sayar.

10.1.3.3. Karar, yeden ve güçlü perdelerini söyler.

10.1.3.4. Hicaz uzzal ve zirgüleli hicaz makamlarında yazılmış seyirleri usul vurarak okur.

10.1.3.5. Hicaz uzzal ve zirgüleli hicaz makamlarındaki eserleri usul vurarak okur.

10.1.4. Karcığar Makamı

10.1.4.1. Karcığar makamının hangi dörtlü ve beşlilerden oluştuğunu açıklar.

10.1.4.2. Karcığar makamının perdelerini sırasıyla sayar.

10.1.4.3. Karar, yeden ve güçlü perdelerini söyler.

10.1.4.4. Karcığar makamında yazılmış seyirleri usul vurarak okur.

10.1.4.5. Karcığar makamındaki eserleri usul vurarak okur.

10.1.5. Saba Makamı

10.1.5.1. Saba makamının hangi dörtlü ve beşlilerden oluştuğunu açıklar.

10.1.5.2. Saba makamının perdelerini sırasıyla sayar.

10.1.5.3. Karar, yeden ve güçlü perdelerini söyler.

10.1.5.4. Saba makamında yazılmış seyirleri usul vurarak okur.

10.1.5.5. Saba makamındaki eserleri usul vurarak okur.

10.1.6. Nihavent Makamı

10.1.6.1. Nihavent makamının hangi dörtlü ve beşlilerden oluştuğunu açıklar.

10.1.6.2. Nihavent makamının perdelerini sırasıyla sayar.

10.1.6.3. Karar, yeden ve güçlü perdelerini söyler.

10.1.6.4. Nihavent makamında yazılmış seyirleri usul vurarak okur.

10.1.6.5. Nihavent makamındaki eserleri usul vurarak okur.

10.1.7. Hicazkâr Makamı

10.1.7.1. Hicazkâr makamının hangi dörtlü ve beşlilerden oluştuğunu açıklar.

10.1.7.2. Hicazkâr makamının perdelerini sırasıyla sayar.

10.1.7.3. Karar, yeden ve güçlü perdelerini söyler.

10.1.7.4. Hicazkâr makamında yazılmış seyirleri usul vurarak okur.

10.1.7.5. Hicazkâr makamındaki eserleri usul vurarak okur.

10.1.8. Kürdilihicazkâr Makamı

10.1.8.1. Kürdilihicazkâr makamının hangi dörtlü ve beşlilerden oluştuğunu açıklar.

10.1.8.2. Kürdilihicazkâr makamının perdelerini sırasıyla sayar.

10.1.8.3. Karar, yeden ve güçlü perdelerini söyler.

10.1.8.4. Kürdilihicazkâr makamında yazılmış seyirleri usul vurarak okur.

10.1.8.5. Kürdilihicazkâr makamındaki eserleri usul vurarak okur.

10.1.9. Hüzzam Makamı

10.1.9.1. Hüzzam makamının hangi dörtlü ve beşlilerden oluştuğunu açıklar.

10.1.9.2. Hüzzam makamının perdelerini sırasıyla sayar.

10.1.9.3. Karar, yeden ve güçlü perdelerini söyler.

10.1.9.4. Hüzzam makamında yazılmış seyirleri usul vurarak okur.

10.1.9.5. Hüzzam makamındaki eserleri usul vurarak okur (TTKB, 2016, 15).

Türk Sanat Müziği Teori ve Uygulaması Dersinin ünite, konu ve kazanımlarının, 9 ve 10. sınıf düzeylerinde verilmesi gerektiği göz önünde bulundurulduğunda, yoğun bir yapıya sahip olduğu düşünülmektedir. Araştırmanın temel çıkış noktası olan bu tespit sebebiyle, Türkiye'nin farklı bölgelerindeki Güzel Sanatlar Liselerinde, Türk Sanat Müziği Teori ve Uygulaması Dersine giren öğretmenlerinin görüşleri alınmıştır.

\section{Yöntem}

Araştırma, Güzel Sanatlar Liselerindeki Türk Sanat Müziği Teori ve Uygulaması Dersi öğretmenlerinin görüşlerine yer verilerek dersin işlevselliği ile ilgili sorunların tespitine yönelik olması bakımından betimsel bir çalışmadır. Betimsel (descriptive) araştırmalar, verilen bir durumu olabildiğince tam ve dikkatli bir şekilde tanımlar (Büyüköztürk, 2010, s.21). Kaptan'a (1998) göre betimsel çalışmalar; olayların, objelerin, varlıkların, kurumların, gurupların ve çeşitli alanların "ne" olduğunu betimlemeyi amaçlayan çalışmalardır. Betimleme araştırmaları, mevcut olayların daha önceki olay ve koşullar ile ilişkilerini de dikkate alarak, durumlar arasındaki etkileşimi açıklamayı hedef alır. 
Araştırmada; nitel ve nicel araştırmaların bir arada kullanıldığı karma yöntem uygulanmıştır. Karma yöntemler, araştırma sürecinde araştırmacının kendisinden veya araştırmanın doğasından kaynaklanabilecek yanlııkları en aza indirgemesi bakımından büyük katkılar sağlayarak, araştırmanın niteliğini arttırmaktadır. Yapılan araştırmada veri kaynaklarını çeşitlendirmek, elde edilecek sonuçların daha geçerli olmasını sağlamaktadır (Creswell \& Clark, 2007, akt. Ünal, 2011). Yurt içi ve yurt dışı literatür taraması yapılarak oluşturulan veri toplama araçlarının iyileştirilmesine katkıda bulunacak durumlar tespit edilmiştir. Taslak olarak oluşturulan anket formu uzman görüşlerine sunulmuş, yapılan gerekli düzenleme ve değişikliklerden sonra çalışma grubuna uygulanarak veriler toplanmıştır. Toplanan verilerin nitel ve nicel çözümlenmesinden sonra elde edilen bulgular düzenlenerek yorumlanmıştır.

Araştırmanın çalışma grubunu Türkiye'nin farklı coğrafik bölgelerindeki Güzel Sanatlar Liselerinden random yolla seçilmiş 16 Türk Sanat Müziği Teori ve Uygulaması Dersi öğretmeni oluşturmaktadır.

Tablo 1. Çalışma grubunun cinsiyet dağılımları

\begin{tabular}{ccc}
\hline Cinsiyet & Frekans (f) & Yüzde (\%) \\
\hline Kadın & 6 & 37,5 \\
Erkek & 10 & 62,5 \\
\hline Toplam & 16 & 100 \\
\hline
\end{tabular}

Tablo 2. Çalışma grubunun mezun olduğu üniversite dağılımları

\begin{tabular}{lll}
\hline Üniversite Adı & Frekans (f) & Yüzde (\%) \\
\hline Karadeniz Teknik Üniversitesi & 2 & 12,5 \\
Selçuk Üniversitesi & 1 & 6,3 \\
Pamukkale Üniversitesi & 2 & 12,5 \\
Yüzüncü Yıl Üniversitesi & 3 & 18,8 \\
Mehmet Akif Ersoy Üniversitesi & 1 & 6,3 \\
Abant İzzet Baysal Üniversitesi & 3 & 18,8 \\
İnönü Üniversitesi & 1 & 6,3 \\
Marmara Üniversitesi & 1 & 6,3 \\
Süleyman Demirel Üniversitesi & 1 & 6,3 \\
Dicle Üniversitesi & 1 & 6,3 \\
\hline Toplam & 16 & 100 \\
\hline
\end{tabular}

Tablo 3. Çalışma grubunun mezun olduğu bölüm türü dağılımları

\begin{tabular}{lll}
\hline Bölüm Türü & Frekans (f) & Yüzde (\%) \\
\hline Müzik Öğretmenliği & 15 & 93,8 \\
Konservatuar Temel Bilimler & 1 & 6,3 \\
\hline Toplam & 16 & 100 \\
\hline
\end{tabular}


Tablo 4. Çalışma grubunun mezun olduğu bölümdeki ana çalgı dağılımları

\begin{tabular}{lll}
\hline Çalgı Adı & Frekans (f) & Yüzde (\%) \\
\hline Ud & 2 & 12,5 \\
Gitar & 2 & 12,5 \\
Keman & 4 & 24,5 \\
Flüt & 2 & 12,5 \\
Viyola & 2 & 12,5 \\
Kanun & 2 & 12,5 \\
Viyolonsel & 1 & 6,3 \\
Ney & 1 & 6,3 \\
\hline Toplam & 16 & 100 \\
\hline
\end{tabular}

Tablo 5. Çalışma grubunun meslekteki çalışma süresi dağııımları

\begin{tabular}{lll}
\hline Yıl Aralığı & Frekans (f) & Yüzde (\%) \\
\hline $5-10$ Yıl & 5 & 31,3 \\
$10-15$ Yıl & 6 & 37,5 \\
$15-20$ Yıl & 5 & 31,3 \\
\hline Toplam & 16 & 100 \\
\hline
\end{tabular}

Tablo 6. Çalışma grubunun güzel sanatlar liselerinde çalışma süresi dağılımları

\begin{tabular}{lll} 
Yıl Aralığı & Frekans (f) & Yüzde (\%) \\
\hline $1-5$ Yıl & 2 & 12,5 \\
$5-10$ Yıl & 11 & 68,8 \\
$10-15$ Yıl & 3 & 18,8 \\
\hline Toplam & 16 & 100 \\
\hline
\end{tabular}

Araştırmada geliştirilen veri toplama aracı üç farklı bölümden oluşmaktadır. illk bölümde Türk Sanat Müziği Teori ve Uygulaması Dersi öğretmenlerinin mezun oldukları üniversite/bölüm, ana çalgıları, meslekteki görev süreleri ile güzel sanatlar liselerindeki görev süreleri gibi demografik bilgileri tespit edilmiştir. İkinci bölümde, 3’lü likert ölçeği kullanılarak, Milli Eğitim Bakanlığı'nın yayınladığı ders kitabının kullanılma sıklığı ile yeterli bulunma durumu, makamların öğretilme süreçleri ve kazanımların yetiştirilebilme durumları saptanmıştır. Üçüncü bölümde ise yarı yapılandırılmış görüşme formu ile öğretmenlerin, dersin mevcut yapısı ile ilgili görüş ve önerilerinin tespiti sağlanmıştır. Veri toplama aracında yer alan likert ölçeği ile elde edilen bulguların analizi "frekans" (f) ve "yüzde" (\%) kullanılarak çözümlenmiştir. Yarı yapılandırılmış sorulardan oluşan görüşme formlarındaki veriler ise betimsel analiz tekniği ile özetlenip yorumlanarak analiz edilmiştir.

Yıldırım ve Şimşek'e (2011) göre; betimsel analizde veriler, daha önceden belirlenen temalara göre özetlenerek yorumlanır. Bu analizde amaç, görüşülen ya da gözlenen bireylerin görüşlerini çarpıcı bir biçimde yansıtmak ve elde edilen verileri düzenlenip yorumlanmış bir şekilde okuyucuya sunmak olduğu için doğrudan alıntılara sık sık yer verilir. Bu doğrultuda, elde edilen veriler önce sistemli ve açık bir şekilde betimlenir, daha sonra bu betimlemeler açıklanıp yorumlanarak neden-sonuç ilişkisi içerisinde birtakım sonuçlara ulaşıır. 


\section{Bulgular}

$>$ Öğretmenlerin Milli Eğitim Bakanlığı’nın Yayınladığı Türk Sanat Müziği Teori ve Uygulaması Ders Kitabını Kullanma Durumları

Öğretmenlerin Milli Eğitim Bakanlığı'nın yayınladığı Türk Sanat Müziği Teori ve Uygulaması Ders Kitabını kullanma durumlarını gösteren tablo aşağıda verilmiştir.

Tablo 7. Öğretmenlerin Türk Sanat Müziği Teori Ve Uygulaması Ders Kitabını kullanma durumu

\begin{tabular}{lll}
\hline Kullanım Durumu & Frekans (f) & Yüzde (\%) \\
\hline Evet & 5 & 31,3 \\
Kısmen & 2 & 12,5 \\
Hayır & 9 & 56,3 \\
\hline Toplam & 16 & 100 \\
\hline
\end{tabular}

Tablo 7 incelendiğinde, Milli Eğitim Bakanlığı tarafından yayınlanan Türk Sanat Müziği Teori ve Uygulaması Ders Kitabı'nı öğretmenlerin \%31,3'ü kullanırken \%56,3'ünün kullanmadığı tespit edilmiştir. Öğretmenlerin $\% 12,5^{\prime} i$ ise kitaptan kısmen yararlandıklarını belirtmişlerdir. Elde edilen verilere göre araştırmaya katılan öğretmenlerin büyük bir bölümünün ders kitabından yeterince yararlanamadığı söylenebilir.

Öğretmenlerin Milli Eğitim Bakanlığın Yayınladığı Türk Sanat Müziği Teori ve Uygulaması Ders Kitabını Yeterli Bulması Durumları

Tablo 8. Öğretmenlerin Türk sanat müziği teori ve uygulaması ders kitabını yeterli bulma durumları dağılımı

\begin{tabular}{lll} 
Yeterli Bulma Durumu & Frekans (f) & Yüzde (\%) \\
\hline Evet & 1 & 6,3 \\
Kısmen & 8 & 50,0 \\
Hayır & 7 & 43,8 \\
\hline Toplam & 16 & 100 \\
\hline
\end{tabular}

Elde edilen veriler incelendiğinde öğretmenlerin \%6,3 gibi çok düşük bir kısmı Milli Eğitim Bakanlığı tarafından yayınlanan Türk Sanat Müziği Teori ve Uygulaması Ders Kitabı'nı yeterli bulmaktadır. Ayrıca öğretmenlerin \%50'si ders kitabını yeterli bulurken $\% 43,8^{\prime} i$ de yetersiz bulmaktadır. Bu bağlamda öğretmenlerin ders kitabını yeterli bulmadıkları ve yeterli düzeyde kullanmadıkları söylenebilir.

\section{Öğretmenlerin Türk Sanat Müziği Teori ve Uygulaması Dersinde Yardımcı Ders Kitabı Kullanma Durumları}

Tablo 9. Öğretmenlerin Türk sanat müziği teori ve uygulaması dersinde yardımcı ders kitabı kullanma durumları dağııımı

\begin{tabular}{lll}
\hline Kullanım Durumu & Frekans (f) & Yüzde (\%) \\
\hline Evet & 7 & 43,75 \\
Hayır & 9 & 56,25 \\
\hline Toplam & 16 & 100 \\
\hline
\end{tabular}

Tablo 9. incelendiğinde öğretmenlerin \%56,25'inin yardımcı ders kitabı kullanmadığı görülmektedir. Bakanlı̆ı̆n yayınladığı kitap öğretmenler tarafından çoğunlukla yeterli bulunmamakta ve derslerde yeterince kullanılmamaktadır. 
Ancak var olan durum tespitine tezat oluşturacak şekilde araştırmaya katılan öğretmenlerinin yarısından fazlası yardımcı ders kitabı kullanmamaktadır.

Türk Sanat Müziği Teori ve Uygulaması Dersi İçerisindeki Makamların Tampere Sisteme Uyarlanmış Şekilde (Yedirilmiş Sesler ile) Öğretilme Durumu

Tablo 10. Öğretmenlerin Türk sanat müziği teori ve uygulaması dersi içindeki makamları tampere sistemde öğretme durumları dağılımı

\begin{tabular}{lll}
\hline Tampere Sistem Kullanımı & Frekans (f) & Yüzde (\%) \\
\hline Evet & 11 & 68,8 \\
Kısmen & 1 & 6,3 \\
Hayır & 4 & 25,5 \\
\hline Toplam & 16 & 100 \\
\hline
\end{tabular}

Elde edilen veriler incelendiğinde öğretmenlerin $\% 68,8^{\prime}$ inin makamları tampere sisteme uyarlanmış biçimiyle gerçekleştirdikleri söylenebilir. Bu doğrultuda öğretmenlerin makamları Milli Eğitim Bakanlığı'nın Öğretim Programında belirttiği üzere, Arel-Ezgi ses sistemine uygun olarak yeteri kadar öğretmedikleri söylenebilir.

H. Sadettin Arel ile Suphi Ezgi, eski yazmaları ve Edvarları inceleyerek elden geçirmişlerdir. Ord. Prof. Salih Murad Uzdilek'in, Arel ile Ezgi'nin çalışmalarına katılmasıyla, Türk müziğinin ses fiziği bölümü de bir düzene sokulmuş ve böylece Arel - Ezgi ses sistemi doğmuştur. Bu sistemde, bir sekizlinin birbirine eşit olmayan 24 aralı̆ga bölünmesiyle birlikte 25 ses meydana gelir. İki tam ses arası 9 koma olmasına rağmen Arel ve Ezgi bu komalardan yalnızca 1, 4, 5, 8 ve 9. komalarına sistemlerinde yer vermişlerdir (Urhan, 2017, 21). Sistem, halen günümüzde geçerliliğini devam ettirmektedir.

Türk Sanat Müziği ve Teori ve Uygulaması Dersi İçerisindeki Makamların Yerinden Öğretilmesi Durumu

Tablo 11. Öğretmenlerin Türk sanat müziği teori ve uygulaması dersindeki makamları yerinden öğretme durumları dağılımı

\begin{tabular}{lll}
\hline Yerinden Öğretme & Frekans (f) & Yüzde (\%) \\
\hline Evet & 9 & 56,3 \\
Kısmen & 2 & 12,5 \\
Hayır & 5 & 31,3 \\
\hline Toplam & 16 & 100 \\
\hline
\end{tabular}

Elde edilen veriler incelendiğinde öğretmenlerin \%56,3'ü makamları yerinden öğretmektedir. Elde edilen verilere göre öğretmenlerin çoğunlukla göçürme yapmadıkları görülmektedir. Ancak Türk Sanat Müziği Makamlarının bir çoğu yerinden icra edildiğinde müziksel gelişim dönemleri itibariyle öğrencilerin ses sınırları dışına çıkmaktadır. Göçürme yapılmadan gerçekleştirilen solfej-okuma çalışmalarında öğrencilerin ses aralıkları nedeniyle zorluk yaşayabileceği ve bu kazanımların verimli olarak işlenemeyebileceği söylenebilir. 
Türk Sanat Müziği Teori ve Uygulaması Dersi Kazanımlarının Belirlenen Eğitim-Öğretim Yılı İçerisinde Yetiştirilebilme Durumu

Tablo 12. Öğretmenlerin Türk sanat müziği teori ve uygulaması dersi kazanımlarını yetiştirebilme durumları dağııımı

\begin{tabular}{lll} 
Kazanımları Yetiştirebilme & Frekans (f) & Yüzde (\%) \\
\hline Evet & 3 & 18,8 \\
Kısmen & 3 & 18,8 \\
Hayır & 10 & 62,5 \\
\hline Toplam & 16 & 100 \\
\hline
\end{tabular}

Tablo 12 incelendiğinde öğretmenlerin \%62,5’i Türk Sanat Müziği Teori ve Uygulaması Dersi kazanımlarını belirlenen eğitim-öğretim süresi içerinde yetiştiremediklerini, \%18,8'i de kısmen yetiştirebildiklerini ifade etmişlerdir. Bu şekilde araştırmaya katılan öğretmenlerin çoğunluğunun belirlenen süre içerisinde hedef kazanımlara ulaşamadıkları söylenebilir.

\section{Türk Sanat Müziği Teori ve Uygulaması Dersi İşlenirken Kullanılan Enstrümanlar}

Tablo 13. Öğretmenlerin Türk sanat müziği teori ve uygulaması dersini işlerken kullandıkları enstrümanların dağılımı

\begin{tabular}{lll}
\hline $\begin{array}{c}\text { Enstrüman } \\
\text { (Tema) }\end{array}$ & Frekans (f) & Yüzde (\%) \\
\hline Ud & 2 & 12,5 \\
Kanun & 4 & 25,0 \\
Keman & 2 & 12,5 \\
Bağlama & 1 & 6,25 \\
Piyano & 13 & 81,25 \\
Ritim Çalgıları & 1 & 6,25 \\
Ney & 1 & 6,25 \\
\hline Toplam & 24 & 100 \\
\hline
\end{tabular}

Elde edilen veriler incelendiğinde öğretmenlerin \%81,25'inin Türk Sanat Müziği Teori ve Uygulaması Dersinde piyano kullandıkları tespit edilmiştir. Piyanoda Türk Sanat Müziği'ne ait koma değerlerinin icra edilebilmesi mümkün değildir. Bu derste sadece piyano kullanılarak makamlardaki komalarının duyurulamayacağı ve bu nedenle dersin piyano ile işlenmesinin mevcut kazanımları gerçekleştirmek için uygun olmadığı söylenebilir.

\section{Öğretmenlerin Türk Sanat Müziği Teori ve Uygulaması Dersi Kazanımlarının Öğretilebileceğini Düşünme Durumları}

Araştırmanın bu bölümünde, katılımcı öğretmenlere Türk Sanat Müziği Teori ve Uygulaması dersinde yer alan kazanımların öğretilip öğretilemeyeceği konusundaki görüşleri açık uçlu soru ile yöneltilip betimsel analiz tekniklerine göre yorumlanmıştır. Öğretmenlerin, Türk Sanat Müziği Teori ve Uygulaması dersinde yer alan kazanımların öğretilip öğretilemeyeceği konusundaki görüşleri tablo 14'te gösterilmiştir. 
Tablo 14. Öğretmenlerin Türk sanat müziği teori ve uygulaması dersi kazanımlarının öğretilebileceğini düşünme durumları

\begin{tabular}{|c|c|c|}
\hline Tema & Katılımcı (f) & Yüzde (\%) \\
\hline $\begin{array}{l}\text { Dersin kazanımları } 9 \text { ve } 10 . \\
\text { Sınıf düzeyinde öğretilemez }\end{array}$ & 9 & 56,25 \\
\hline Bazı kazanımlar öğretilebilir & 4 & 25,0 \\
\hline Öğretilemez & 3 & 18,75 \\
\hline Öğretilebilir & 3 & 18,75 \\
\hline $\begin{array}{l}9 \text { ve } 10 \text {. Sınıf düzeyinde batı } \\
\text { müziği ağırlıklı olmalı }\end{array}$ & 4 & 25,0 \\
\hline $\begin{array}{l}\text { Bu ders } 11 \text { ve } 12 . \text { Sınıf } \\
\text { düzeyinde verilmeli }\end{array}$ & 7 & 43,75 \\
\hline Toplam & 30 & 100 \\
\hline
\end{tabular}

Tablo 14. incelendiğinde; Kazanımlar 9 ve 10. sınıf düzeyinde öğretilemez $(\% 56,25)$ ve bu ders 11 ve 12 . sınıf düzeyinde verilmeli $(\% 43,75)$ temaları ön plana çıkmaktadır. Buna bağlı olarak öğretmenlerin Türk Sanat Müziği Teori ve Uygulaması Dersi'ni sınıf düzeyine uygun bulmadıkları ve öğretilemeyeceğini düşündükleri söylenebilir. Katılımcılardan bazılarının ifade ettiği özgün görüşlerden bazıları aşağıdaki gibidir:

"Sınıf seviyelerine dersin uygun olmadığını düşünüyorum. Türk Halk Müziği Teori ve Uygulaması dersi 9 ve 10. Sınıf düzeyinde, Türk Sanat Müziği Teori ve Uygulaması Dersi ise 11 ve 12. Sınıf düzeyinde verilmeliydi." (K11)

“9 ve 10. Sınıf düzeyinde öncelikle tampere sistem oturtulmalı daha sonraki sınıf düzeylerinde basit, birleşik ve şed makamlara geçiş yapılmalı." (K16)

“Ders Türk Müziği enstrümanları ile işlenirse öğretilebilecek düzeydedir.” (K10)

"Bu ders öğretilebilir, öğrenciler komalı sesleri çok rahat verebiliyor." (K8)

“Batı Müziği Teori ve Uygulaması Dersi ile Türk Sanat Müziği Teori ve Uygulaması derslerinin aynı anda işlenmesi ve iki dersin de müfredatının yoğun olması sebebiyle kazanımlar kısmen gerçekleştirilebiliyor." (K5)

“Henüz aralık, vuruş ve nota bilgisi tam olmayan 9. sınıf öğrencilerine, her türlü tartımın olduğu parçalar, usüller vurdurularak, komalı eserlerin solfejleri yaptırılmaya çalışılıyor. Bu ders 10. sınıfta başlamalıydı." (K2)

\section{Sonuçlar}

Araştırma sonucunda Bakanlığın yayınladığı Türk Sanat Müziği Teori ve Uygulaması Ders Kitabı'nın bu dersi veren öğretmenler tarafından yeterli bulunmadığı ve genellikle kullanılmadığı görülmektedir. Öğretmenlerin mevcut ders kitabını kullanmama durumlarının ek-kaynak kitaplara başvurmalarına sebep olacağı düşünülmektedir. Ancak elde edilen bulgular doğrultusunda öğretmenlerin çoğunlukla ek-kaynak kitap kullanmadıkları da tespit edilmiştir. Bu durumun dersin uygulanabilirlik düzeyi ve işlevselliği ile ilgili belirsizliklere sebep olduğu söylenebilir. Ayrıca öğretmenlerin ders içeriğindeki makamları öğretirken çoğunlukla tampere sisteme uyarlama yaptıkları ve yedirilmiş sesler kullandıkları sonucuna ulaşılmıştır. Bu durumda makamların öğrencilere, dersin öğretim programının amaçlarında belirtildiği üzere, Arel-ezgi ses sistemi kapsamında, geleneksel perdeler ve aralıklar kullanılarak öğretilmediği görülmektedir. Mevcut durum göz önünde bulundurulduğunda dersin hedef kazanımlar doğrultusunda yürütülemediği söylenebilir.

Türk Sanat Müziği Teori ve Uygulaması Dersi içindeki makamlar ile ilgili kazanımlar işlenirken göçürme yapılmadığı, yerinden öğretim gerçekleştirildiği tespit edilmiştir. Bu bağlamda öğrencilerin ses sınırları nedeniyle solfej ve eser okuması yaparken zorlanacağı söylenebilir. Bununla birlikte öğretmenlerin, Türk Sanat Müziği Teori ve Uygulaması Dersi kazanımlarını belirlenen eğitim-öğretim süresi içerisinde yetiştiremediklerini düşündükleri görülmektedir. 
Türk Sanat Müziği Teori ve Uygulaması Dersi işlenirken en çok kullanılan enstrümanın piyano olduğu tespit edilmiştir. Ders esnasında Türk Müziği enstrümanı kullanan, makamları geleneksel perde ve aralıkları ile öğreten öğretmenlerin, mezun oldukları üniversitelerdeki ana çalgıları da yine Türk Müziği enstrümanlarıdır. Bu durumda Türk Sanat Müziği Teori ve Uygulaması Dersine girecek öğretmenlerin geleneksel perde ve aralıkları verebilecek anatomiye sahip bir Türk Müziği enstrümanını çalabiliyor olması gerektiği görülmektedir.

Araştırmaya katılan müzik öğretmenlerin görüşlerine dayanarak Türk Sanat Müziği Teori ve Uygulaması Dersindeki kazanımların 9. Sınıf öğrencileri tarafından uygulanabilmesinde güçlüklerle karşılaşıldığı görülmektedir. Öğretmenler çoğunlukla bu dersin 11. ve 12. sınıf düzeyinde işlenmesi gerektiğini belirtmişlerdir.

\section{5. Öneriler}

Araştırmada elde edilen sonuçlara göre aşağıda belirtilen öneriler sunulmuştur.

1. Milli Eğitim Bakanlığı tarafından yayınlanan Türk Sanat Müziği Teori ve Uygulaması Ders Kitabında yer alan konuların sınıf düzeylerine göre yeniden düzenlenmesinin, dersin hedeflerine ulaşılması bakımından önemli olduğu düşünülmektedir.

2. Solfej ve eser okuma yaptırıırken öğrencilerin ses aralıkları nedeniyle karşılaşabilecekleri güçlükleri en aza indirgeyebilmek açısından makamlarda göçürme yapılması önerilmektedir.

3. Türk Sanat Müziği Teori ve Uygulaması Dersi Öğretim Programı güncellenerek; sınıf düzeylerine daha uygun kazanımların belirlenmesi ve mevcut kazanımların değiştirilmesiyle birlikte dersin içeriği hafifletilebilir.

4. Türk Sanat Müziği Teori ve Uygulaması Dersi öğretmenlerinin, öğrencilere geleneksel perde, koma ve aralıkları verebilmeleri için ders esnasında Türk Müziği enstrümanı kullanmaları ve makamları yedirilmiş sesler yerine komalı halleriyle öğretmeleri gerekmektedir.

5. Müziksel İşitme Okuma ve Yazma branş öğretmenlerine ait olan derslerin isim ve içerikleri değiştirilmiş ancak bu öğretmenlerin kadrolarındaki branşı Müziksel İşitme Okuma ve Yazma öğretmeni olarak değiştirilmeden bırakılmıştır. Bu nedenle Türk Sanat Müziği alanında yetkin olmayan öğretmenler de Türk Sanat Müziği Teori ve Uygulaması derslerinin yürütebilmektedir. Mevcut durum Güzel Sanatlar Lisesi normlarında ve branş isimlerinde güncellemeye gidilmesini zorunlu kılmaktadır.

6. Türk Sanat Müziği Teori ve Uygulaması Dersinin daha üst sınıf düzeylerinde okutulması ve 9. Sınıf düzeyinde öncelikle tampere sistemin oturtularak daha sonra geleneksel perde, aralık, usül ve komalara geçilmesinin, öğrencilerin dersin kazanımlarını daha kolay gerçekleştirebilmesi için önemli olduğu düşünülmektedir.

\section{Kaynakça}

Büyüköztürk, Ş., Çakmak, E.K., Akgün, Ö.E., Karadeniz, Ş. ve Demirel, F. (2010). Bilimsel Araştırma Yöntemleri. Ankara: Pegem Akademi.

Creswell, J.W., Clark V.L.P. (2007). Designing and Conducting Mixed Methods Research. London, New Delhi: Sage

Gedikli, N. (1999) Ülkemizde Etki ve Sonuçlarıyla Uluslararası Sanat Müziği. İzmir: Ege Üniversitesi Basımevi

Judetz-Popescu, E. (2007). Meanings in Musical Culture. İstanbul: Pan Yayıncllık.

Kaptan, S. (1998). Bilimsel Araştırma ve Istatistik Teknikleri. Ankara: Bilim Yayınevi.

Kuyucu, M, M. (2010). Ortaöğretimde öğrenim gören öğrencilerin Türk Sanat Müziğine yaklaşımı. Yayımlanmamış Yüksek Lisans Tezi, İstanbul Teknik Üniversitesi, İstanbul.

TTKB. (2016a). Güzel Sanatlar Lisesi Türk Sanat Müziği Teori ve Uygulaması Dersi Öğretim Programı 9 ve 10. Sınıflar. http://ttkb.meb.gov.tr/program.aspx. (2018, Haziran 23)

TTKB. (2016b). Güzel Sanatlar Lisesi Batı Müziği Teori ve Uygulaması Dersi Öğretim Programı 9 ve 10. Sınıflar. http://ttkb.meb.gov.tr/program.aspx. (2018, Mayıs 17)

Urhan, Ö, Z. (2017). Braille nota sistemi ile Türk musikisi basit makamları. Yayımlanmamış Yüksek Lisans Tezi, Fırat

Üniversitesi, Elazıı̆. 
Ünal, M. (2011). Avrupa Birliği Erasmus öğrenci öğrenim hareketliliği programının CIPP "bağlam, girdi, süreç, ürün" modeline göre değerlendirilmesi. Yayımlanmamış Doktora Tezi. Gazi Üniversitesi, Ankara.

Yıldııım, A. ve Şimşek, H. (2011). Sosyal Bilimlerde Nitel Araştırma Yöntemleri. Ankara: Seçkin Yayıncılık. 